J. Natn. Sci. Coun. Sri Lanka 199422 (Suppl. A):S67-S75

\title{
BIOTECHNOLOGY IN THE BREWERY
}

\author{
S. GAMAGE \\ Ceylon Breweries Ltd., Nuwara Eliya.
}

\section{Introduction}

The Ceylon Brewery Ltd., (CBL) brewers \& bottlers of Lion Beers are renowned for their reliance on traditional methods to maintain the quality of Lion Beers. The Brewery in Nuwara Eliya dates back to 1881, first under British brewmasters and now under the guidance of experienced local brewmasters with over 70 years of collective brewing experience. The CBL produces several popular brands such as Lion Lager, Lion Pilsner, Royal Pilsner and Lion Stout. The internationally popular Danish beer Carlsberg is now being brewed in Sri Lanka and was introduced to the market since early 1992 by the CBL. Today the CBL has substantially increased its production of these high quality products which has brought them into international fame in many competitions by winning several gold medals and other high ranking awards.

\section{A Brief Outline of the Brewing Process}

Brewing is the procedure used for producing the mild alcoholic beverages called beer from various natural starchy materials through the medium of fermentative process of yeast. The making of alcoholic beverages is nearly as old as mankind itself. Beer is known to have been widely used as a drink in ancient Egypt.

\section{Brewing Materials}

The principal raw materials of beer processing are (1) barley malt (2) adjuncts (3) hops (4) yeast (5) water (Table 1).

Malt: The barley seed that has been germinated is used in the malting process. Malt is prepared from either 2 row or 6 row barley. During the malting process the raw hard, flat tasting barley is changed to crisp mellow sweet tasting malt. The character of the malt plays an important role in the beer that is to be produced. The percentage of malt used in the different brands of beer varies from $65 \%$ to $90 \%$ of the total brewing material.

Adjuncts: Cereal adjuricts are important in the making of pale, very stable and sparkling beers. Since barley malt usually contains more enzymes than are necessary for the splitting of the available starches the mixing of malt with larger or small amounts of unmalted, cereals or starchy material is widely used today.

Hops: Hops are used for flavouring of beers. They impart a bitter taste and pleasant aroma. 
Table 1

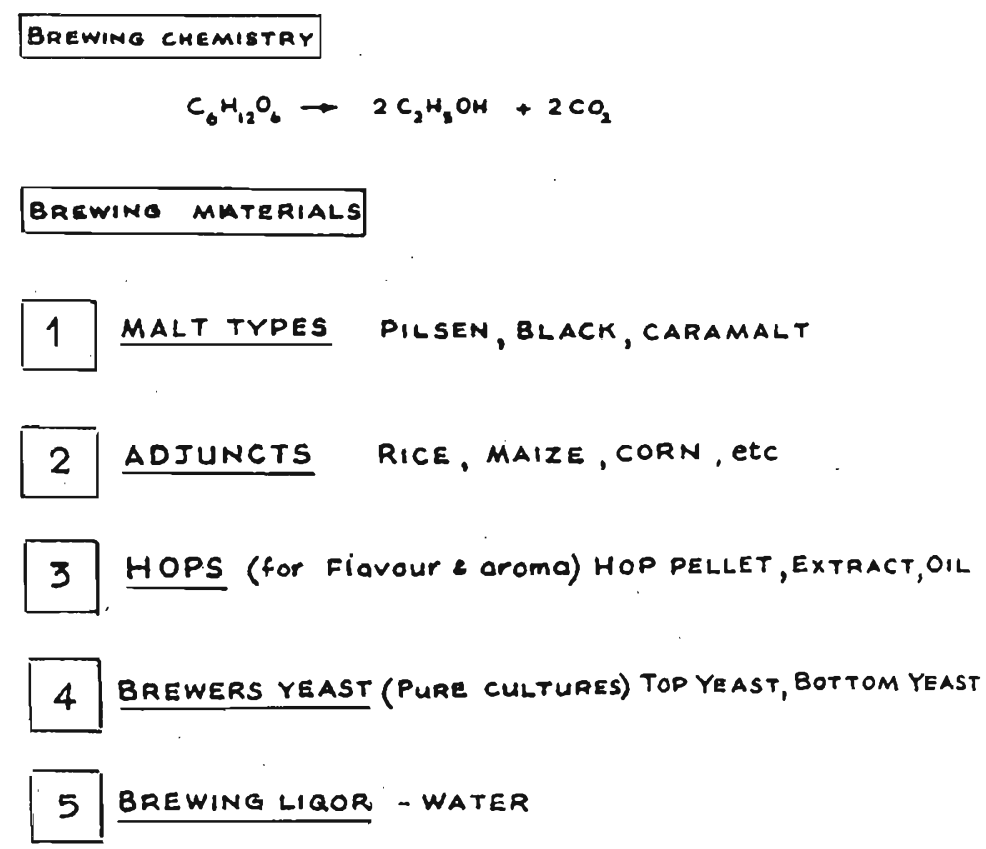

Yeast: Yeast is vitally important in the process of making beer. Yeast for brewing is generally propagated from single cell cultures (pure cultures) and is usually recovered after fermentation is completed and used again for many generations. Brewers yeast is not only selected on the sole basis of fermenting power but also decidedly on the flavour it imparts to the final product.

Water: The successful brewing should depend upon the 'right' kind of water. The mineral content in brewing water is adjusted according to the process. The $\mathrm{pH}$ is also of great importance for the biochemical reactions taking place during brewing. Smaller adjustments for hardness can be made by the addition of various salts or by acidification.

Brewhouse Operations: Between the dry crispy malt grain and the cool satisfying glass of beer there are many production steps. A flow sheet for production of beer is shown Fig. 1.

Beer processing is carried out in four main steps (Fig. 2):
(1) wort production
(2) fermentation
(3) storage
(4) filtration \& bottling

Wort Production : Starch and enzymes derived from malt must first be ground to coarse powder and infused in water. Other starchy adjuncts such as rice, maize, corn or various sugar products are often used to replace or supplement portions of the malt. 


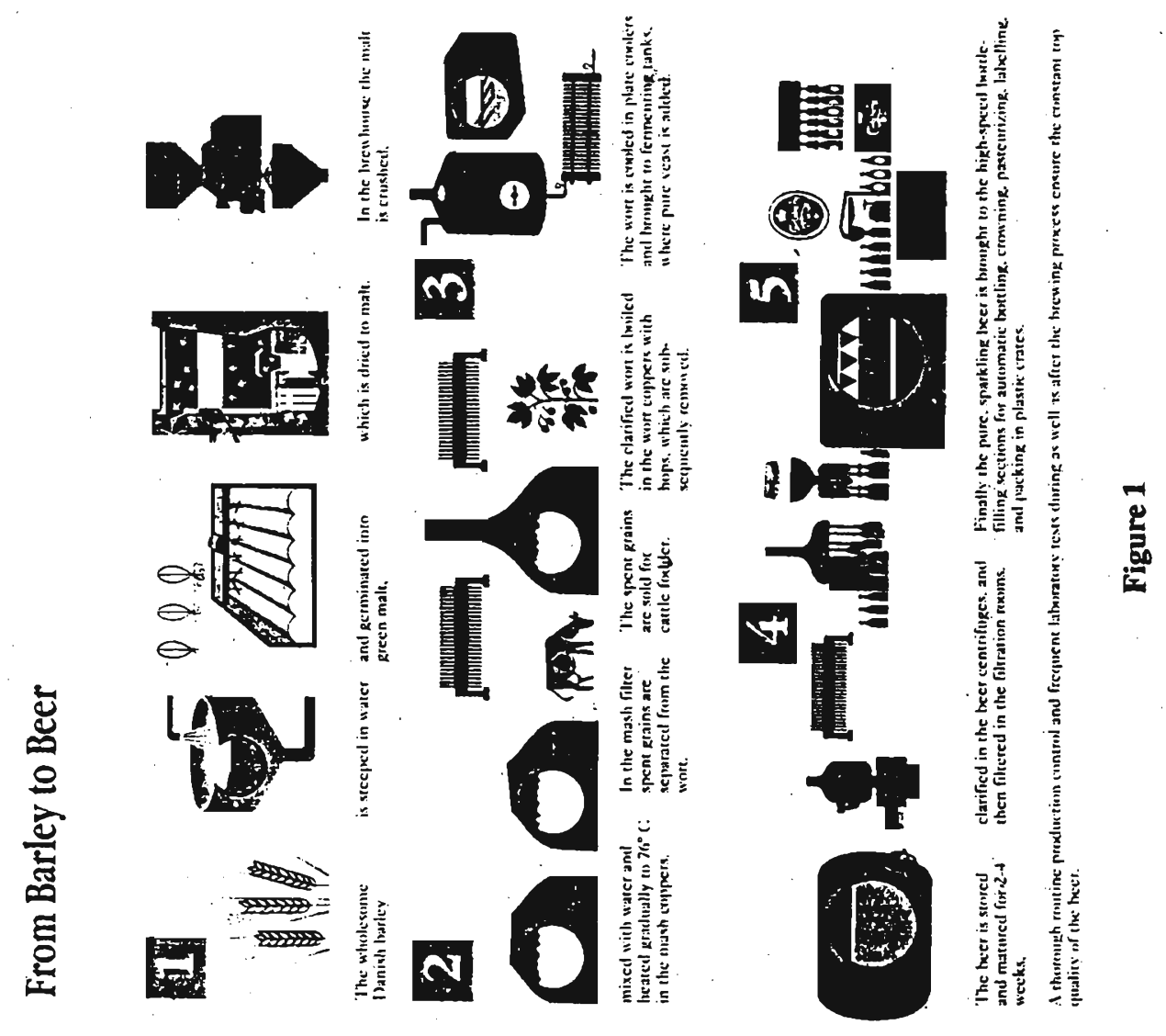




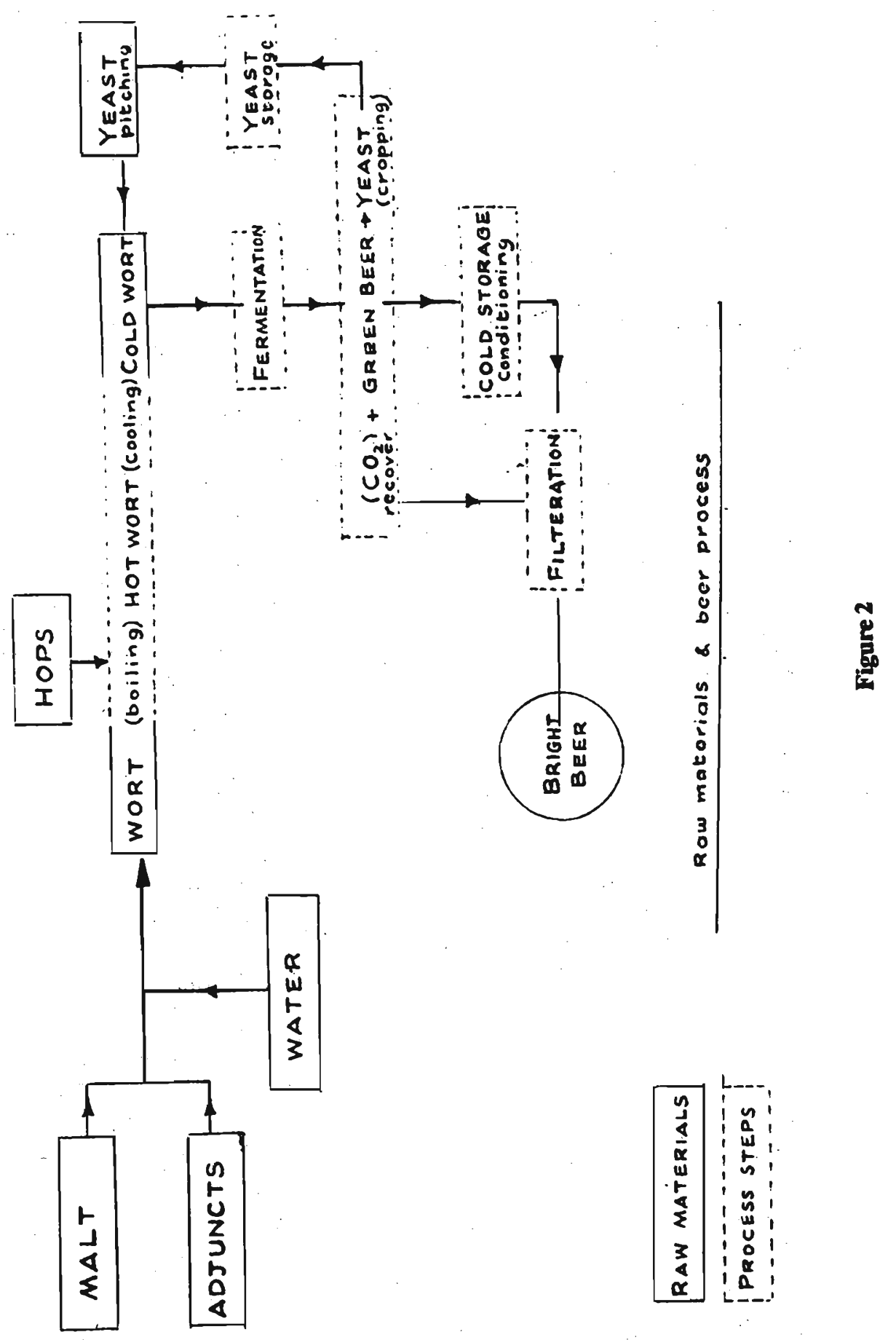


This mixture called the mash is carried through a definite heating cycle to solubilise proteins and convert the starch into soluble sugar dextrins. The soluable extract is washed (sparged) with hot water until all available sugar material is collected, which is then boiled with the addition of hops for a period of $11 / 2$ to $2 \mathrm{hrs}$. During the boiling process the bitter substances of hops are derived into the liquid, and the insoluble protein substances of malt extract are broken down by the fermentation of protein-tannin complexes. The tannin is derived from the hops. The hot liquid is then cooled down to the fermentation temperature.

Fermentation: Yeast is then added (pitching) and fermentation allowed to proceed. Fermentation may be the key process of brewing and all fermentable sugars are consumed by the yeast and only non fermentable dextrins remain in the beer. Efforts to attain this state of 'end fermentation' are governed by necessary regard for the beer flavour. A bottom fermenting yeast is employed for lager and pilsner beer and top fermenting yeast added for stout.

Storage: When fermentation is completed the beer is transferred to storage tanks to age and clarify at low temperatures.

Filtration \& Bottling: Beer is carbonated with the $\mathrm{CO}_{2}$ collected during the fermentation and complete the process to yield the beverage beer as we know it.

\section{Type of Beers (Table 2)}

There are two basic types of beers viz. top fermented and bottom fermented. The names are derived from the respective types of yeast used - after fermentation the yeast either floats on top of the beer or settles on the bottom of the fermenting tank. Top yeast is the original type used in brewing and is still used for ale and stout. 'Bottom yeast' was developed for brewing of all other beers, so called lager and pilsner beers. Various strains of both yeast types have individual flavours.

Top fermenting type Stout : Stout is very dark brown beer with sweet, slightly burnt taste and strong flavour. It is strongly hopped and contains $7.5 \%$ alcohol by volume. Stout is brewed the difference being in the amounts of black malt, caramalt and hops used.

Top fermenting type Lager: The name lager is derived from German word for 'storage' and was originally applied to all bottom fermented beers. In the trade 'Lager beer' has been applied to mellow amber coloured beer. It contains $4.0 \%$ alcohol by volume. Pilsner beer is pale with distinct dry hop flavour and contains $4.0 \%$ to $4.5 \%$ alcohol by volume.

Properties of glass of beer: The quality consists of the following:
(1) aroma
(2) flavour
(3) $\mathrm{CO}_{2}$ saturation
(4) clarity and appearance
(5) head (foam) formation (6) stability of head. 
Nutritional value of beer : All beer drinkers know that they enjoy a good quality beer but few are aware of its nutritional value. Beer contains essential proteins, a number of important $\mathrm{B}$ vitamins derived from yeast plus $\mathrm{Ca}^{++}, \mathrm{PO}_{4}, \mathrm{~K}^{+}$and $\mathrm{Mg}^{++}$and other mineral ingredients.

Table 2: Comparative Analysis of Varlous Brands

\begin{tabular}{|c|c|c|c|c|c|c|}
\hline Brand & $\begin{array}{l}\text { Colour } \\
\text { (Lovibond }\end{array}$ & $\begin{array}{l}\text { Alc. } \\
\text { by vol }\end{array}$ & $\mathrm{pH}$ & $\begin{array}{l}\mathrm{CO}_{2} \mathrm{Sol} . \\
\text { vol }\end{array}$ & $\begin{array}{l}\text { Type of } \\
\text { yeast strain }\end{array}$ & Characteristics \\
\hline Lion lager & 7.0 & 4.0 & 4.21 & 2.75 & $\begin{array}{l}\text { Bottom } \\
\text { fermenting }\end{array}$ & $\begin{array}{l}\text { Light colour, light } \\
\text { bodied with hop } \\
\text { aroma }\end{array}$ \\
\hline Lion pilsner & 7.5 & 4.2 & 4.30 & 2.80 & $\begin{array}{l}\text { Bottom } \\
\text { fermenting }\end{array}$ & $\begin{array}{l}\text { Pale with distinct } \\
\text { flavour }\end{array}$ \\
\hline Royal pilsner & 9.0 & 4.5 & 4.32 & 2.80 & $\begin{array}{l}\text { Bottom } \\
\text { fermenting }\end{array}$ & $\begin{array}{l}\text { Amber colour, } \\
\text { heavy bodied, } \\
\text { strongly hopped }\end{array}$ \\
\hline Lion stout & 250 & 7.5 & 4.18 & 2.50 & $\begin{array}{l}\text { Top } \\
\text { fermenting }\end{array}$ & $\begin{array}{l}\text { Very dark, burnt } \\
\text { taste, creamier } \\
\text { head, strongly } \\
\text { hopped }\end{array}$ \\
\hline Carlsberg & 6.5 & 5.0 & 4.28 & 2.80 & $\begin{array}{l}\text { Bottom } \\
\text { fermenting }\end{array}$ & $\begin{array}{l}\text { Light bodied, light } \\
\text { colour \& higher } \\
\text { alchol content }\end{array}$ \\
\hline
\end{tabular}

Quality Control Work: Continuous quality control and a thorough routine production check at every phase of the brewing process from raw materials to finished product guarantees a consistent high quality of beer. (Tables 3 \& 4) Quality assurance work of beers related to following functional areas have been carried out by the quality control department in the CBL.

(1) Raw Materials: Ensuring the quality of water, malt, hops, maize, rice, bottles, crowns, labels, filter aids etc.

(2) Process Control: Beer processing at following stages wort, fermenting, storage, treatment, bright beer and finished beer.

(3) Microbiology: The microbiological aspect of quality control in beer production are the following

Handling and propagation of brewers yeast.

Prevention of contamination in brewing equipment.

Sampling and analysis of CIP water, yeast, wort, fermenting, storage and finished beer. 
Packaging \& Storage: Control of filling levels, leaking crowns, display of labels, date coding, wooden crates, sleeves and partitions and corrugated cartons.

By Products: Brewers grains are that fraction of the brewing materials that remain as a redidue in the mash tun after the wort collection is completed. It is an excellent animal feed, consisting mainly of protein, carbohydrates, minerals and fibre materials.

Brewers Yeast : If available in large quantities can be utilized for the production of Marmite as done in the U.K. $\mathrm{CO}_{2}$ gas collected during the fermentation is purified, liquefied and utilized for the purpose of carbonation in bright beer.

Table 3

\section{Quality Assurance (Microbiological)}

- Quality of Design: Brewers' yeast

- Quality of Manufacture: Brewers' yeast

Contaminants

- Quality of Marketing

\section{Microbiological Quality Control}

- Yeast Propagation

- Process Precautions

- Laboratory Documentation

\section{Biological Control}

Beer Production

\begin{tabular}{|l|l|l|l|}
\hline $\begin{array}{l}\text { Process } \\
\text { Wort handling }\end{array}$ & $\begin{array}{l}\text { "Quality risk" } \\
\text { Temporary } \\
\text { off-flavour } \\
\text { Constant } \\
\text { off-flavour (often } \\
\text { not realised, i.e. } \\
\text { "house-flavour") }\end{array}$ & $\begin{array}{l}\text { Process precaution } \\
\text { Cleaning, } \\
\text { Sterilisation } \\
\text { Pitching rate, Yeast } \\
\text { discarding, } \\
\text { Cleaning, } \\
\text { Sterilisation } \\
\text { Cleaning, } \\
\text { Sterilisation } \\
\text { Storage }\end{array}$ & $\begin{array}{l}\text { Laboratory control } \\
\text { Plate counts }\end{array}$ \\
Bottling & $\begin{array}{l}\text { Yeast cell counts, } \\
\text { Plate counts } \\
\text { Haze formation, } \\
\text { Off-flavour, } \\
\text { Ropines, } \\
\text { Overpressure }\end{array}$ & $\begin{array}{l}\text { Filtration, } \\
\text { Cleaning, } \\
\text { Sterilisation }\end{array}$ & $\begin{array}{l}\text { Membrane } \\
\text { filtrations, Plate } \\
\text { counts }\end{array}$ \\
\hline
\end{tabular}


Table 4

\section{The Brewery Process}

Unsterile zone:

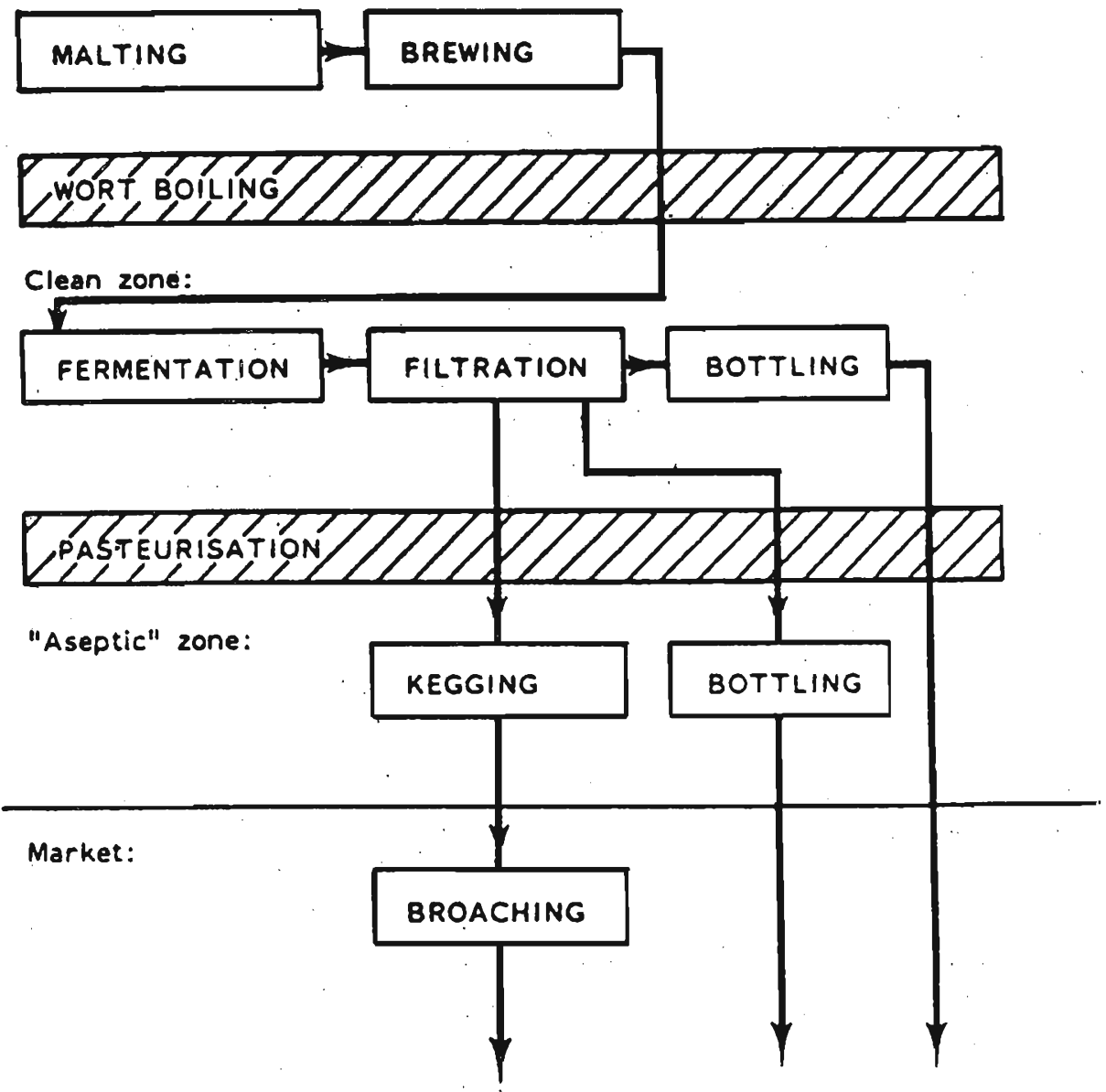

Signatures: $\square$ A process where microorganisms may be introduced.

QZZ A process where all microorganisms are killed. 


\section{Future Projections}

The CBL has just completed an upgrading programme in certain important areas when the linkage with Carlsberg was finalised. The Company has invested 15 million rupees on new equipment to brew the new beer. A major portion of this investment had gone for the equipment required to handle the particular strain of yeast required in the brewing of Carlsberg. The rest of the investment was to upgrade the quality assurance division of the Company.

CBL now produces $75,000 \mathrm{HL}$, which is its maximum capacity, utilizing present equipment and old brewing and storage facilities. The Sri Lankan beer market is very small when compared to other countries. The beer consumption per capita is 0.051 whereas Denmark has beer drinking per capita of 1301.

The local beer market shows a 10 to 15 percent growth but a high price factor cripples substantial expansion. Therefore, the CBL has increasing focussed its attention to export markets. CBL now exports Lion Beers to U.K., Germany, Japan, Switzerland, Belgium and France. It is significant that CBL recognised the need for further expansion to reach a target of 150,000 HL by the year 1997.

To brew this volume, the CBL is prepared to make the necessary investment for new brewhouse, fermentation and storage vessels and new machinery and warehouse facilities. At this stage the Company anticipates to begin research work in fermentation, yeast growing and microbiology. Research into brewing will continue to make new discoveries. Beer cannot be synthesized with all the sophistication of silicon chip micro processors, in line GLC and mass spectograph analysis linked to computerized data banks. Processes such as malting, mashing, boiling and fermentation in fact belong to the dark ages.

There is apparently more sophistication in the process that lead up to a glass of beer than all the computers and analytical tools yet devised. 